\title{
Alternative Paths of Green Entrepreneurship: The Environmental Legacies of the North Face's Doug Tompkins and Patagonia's Yvon Chouinard
}

\section{Citation}

Jones, Geoffrey, and Ben Gettinger. "Alternative Paths of Green Entrepreneurship: The Environmental Legacies of the North Face's Doug Tompkins and Patagonia's Yvon Chouinard." Harvard Business School Working Paper, No. 17-034, October 2016.

\section{Permanent link}

http://nrs.harvard.edu/urn-3:HUL.InstRepos:30907316

\section{Terms of Use}

This article was downloaded from Harvard University's DASH repository, and is made available under the terms and conditions applicable to Open Access Policy Articles, as set forth at http:// nrs.harvard.edu/urn-3:HUL.InstRepos:dash.current.terms-of-use\#OAP

\section{Share Your Story}

The Harvard community has made this article openly available. Please share how this access benefits you. Submit a story. 
Alternative Paths of Green Entrepreneurship: The Environmental Legacies of the North Face's Doug Tompkins and Patagonia's Yvon Chouinard

Geoffrey Jones Ben Gettinger

Working Paper 17-034 


\section{Alternative Paths of Green Entrepreneurship: The Environmental Legacies of the North Face's Doug Tompkins and Patagonia's Yvon Chouinard}

Geoffrey Jones

Harvard Business School

Ben Gettinger

Working Paper 17-034 


\title{
Alternative Paths of Green Entrepreneurship: The Environmental Legacies of the North Face's Doug Tompkins and Patagonia's Yvon Chouinard
}

\section{Geoffrey Jones and Ben Gettinger}

\begin{abstract}
This working paper examines the impact of two entrepreneurs who offered alternative paths to reach their shared goal of a more sustainable world. Yvon Chouinard and Doug Tompkins were respective founders of the prominent outdoor apparel brands Patagonia and The North Face. Chouinard pursued incremental sustainability strategies over decades at his firm. Tompkins, who went on to manage the fashion company Esprit, opted in 1989 to exit business entirely having concluded that capitalism could never be sufficiently sustainable to reverse environmental degradation. He purchased 1.5 million hectares of land in Chile and Argentina which he converted to protected areas and national parks. The Chouinard strategy represented best practice green entrepreneurship which if widely adopted might markedly reduce the environmental impact of business, but its full execution appeared possible only because Patagonia was a private company. The Tompkins dual strategy of exit from business and application of entrepreneurial skills to conservation resulted in large environmental gains, including sequestering and storing an estimated 80 million tons of carbon. We lack the metrics and methodologies to compare rigorously which offers the better path to sustainability, but a case can be made that the application of entrepreneurial talents to activities beyond for-profit business (of which conservation is one example) might be a more effective strategy.
\end{abstract}




\section{Alternative Paths of Green Entrepreneurship: The Environmental Legacies of the North Face's Doug Tompkins and Patagonia's Yvon Chouinard ${ }^{1}$}

\section{Geoffrey Jones and Ben Gettinger}

\section{Introduction}

On December 8, 2015, 72-year-old Doug Tompkins, the founder of The North Face, was killed in a kayaking accident on Lake General Carrera, straddling the border between Argentina and Chile in South America. In the weeks that followed, an outpouring of remembrances flowed from newspapers and environmentalists alike. Included in those eulogizing Tompkins was Yvon Chouinard, founder of the equipment company Patagonia and lifelong friend of Tompkins, who had been a member of the paddling expedition that tragically claimed Tompkins's life. ${ }^{2}$

Beyond being avid outdoorsmen, Chouinard and Tompkins had over the course of their 50-year friendship revolutionized the outdoor apparel industry, founding two companies that would come to dominate and lead innovation in the market. More than just successful entrepreneurs, the two shared a strong desire to protect the natural environment. However, Chouinard and Tompkins took radically different approaches to fighting environmental degradation. Chouinard positioned his company as a steward for sustainability, investing in green supply chain initiatives, sourcing organic and recycled raw materials, and allocating a percentage of sales each year to grants serving grassroots organizations. In contrast, Tompkins, critical of the role that business played in environmental degradation, exited the corporate world entirely, and used his wealth to buy land in South America in order to preserve and restore the natural environment. 
These contrasting strategies provide a new lens on current debates about the ability of business to contribute to environmentalism. Forty years ago, business was broadly believed to be the problem, rather than a potential opportunity, for sustainability; however, during the 1980s a new interpretation emerged of business as a potential savior. Among the milestones was John Elkington's co-authored book entitled The Green Capitalists, published in 1987, which described the importance for sustainability of an emergent group of "environmental entrepreneurs." 3 A decade later Elkington launched the concept of a "triple bottom line" of profitability, environmental quality, and social justice (or people, planet and profit) in a book called Cannibals with Forks. ${ }^{4}$ A large scholarly literature has subsequently developed on business and the environment, mostly focused on the sustainability strategies of large corporations. ${ }^{5}$

A smaller literature has explored the phenomenon of green entrepreneurship, alternatively known as environmental, eco or sustainable entrepreneurship. ${ }^{6}$ Practitioners such as Paul Hawken have made the case of the transformational potential of green entrepreneurship. ${ }^{7}$ The scholarly literature has for the most part struggled with clarifying definitional issues, and sought to establish typologies of different types of green entrepreneur. For example, in an early study, Robert Isaak distinguished between "green-green" entrepreneurs, strictly founded on the principles of sustainability, and others. ${ }^{8}$ Liz Walley and David Taylor identified four types of green entrepreneur. Within their taxonomy, “visionary champions” were closest to Isaak’s greengreen entrepreneurs, businessmen who wanted to make societies and economies more sustainable in a radical fashion. "Ethical mavericks" were also values driven, but their ideas emerged from their networks of friends and lifestyle rather than over-riding visions of changing the world. The two other types of green entrepreneurs were profits rather than values driven. "Innovative opportunists" found ecological concerns a profitable niche, while "ad-hoc" green entrepreneurs 
stumbled on ecological businesses again through social or other networks. ${ }^{9}$ An emergent business history literature has confirmed the argument that there is a considerable diversity of types who might be called green entrepreneurs, as well as demonstrating that the phenomenon has deep historical roots. ${ }^{10}$

The primary focus of many studies has often been intent rather than outcomes. This working paper, which is primarily a thought experiment backed up by some empirical data and some major assumptions, addresses the outcomes issue through comparing the different strategies of Chouinard and Tompkins. Both men foresaw the pending environmental crisis decades before notions of climate change, water shortages, and much else, had made their way into popular culture. This paper addresses a number of central questions: Must corporate environmentalism come at the expense of maximizing profit? Is it optimal to have a wealthy philanthropist exert control over foreign land in order to protect threatened habitats? Can a company credibly fight for sustainability initiatives while simultaneously benefiting from a consumer culture that creates waste and degradation? Are entrepreneurial talents more productively used in activities beyond for-profit activities?

\section{Two Entrepreneurial Paths}

\section{Doug Tompkins}

Doug Tompkins was born in 1943 in Conneaut, Ohio. A nonconformist from an early age, Tompkins was expelled from prep school and spent several years’ rock climbing across Europe and the American West. ${ }^{11}$ Wanting to sell premium gear to his compatriot mountaineers and outdoor enthusiasts, Tompkins founded The North Face in 1964 at the age of 21 with an initial investment of five thousand dollars. ${ }^{12}$ The North Face started as a mail order catalog for 
backpacking and climbing equipment and by 1966 had opened up a flagship brick-and-mortar retail store in San Francisco. Though remembered as the creator of the company, Tompkins's tenure as CEO of The North Face was short-lived. He sold the company for \$50,000 in 1967 to Hap Klopp, a recently-minted Stanford MBA, and immediately traveled to the Patagonia region of Argentina with Chouinard and a few other friends for several weeks of climbing and hiking. ${ }^{13}$

While he was exploring Patagonia, Tompkins's wife Susie and a friend started a clothing label, Plain Jane Dress Company. By the time Tompkins had returned from South America, Plain Jane had begun taking off. He joined the company as a partner, leading marketing and sales. ${ }^{14}$ The company, renamed Esprit de Corp, grew tremendously throughout the 1970s. By 1985, sales had reached \$700 million and Esprit had pioneered the now common "shop within a shop" concept at partnering department stores. ${ }^{15}$

However, the late 1980s marked turmoil for both the Tompkins's and the company. Sales began to falter as Esprit lost market share to competitors, Esprit incurred its first financial losses, and the Tompkins's marriage frayed. In 1989, shortly after filing for divorce, Tompkins sold his stake in Esprit to Susie for $\$ 170$ million. ${ }^{16}$ He would never reenter the business world.

\section{Yvon Chouinard}

Yvon Chouinard was born in Lisbon, Maine in 1938. A self-described high school "misfit," Chouinard took more of an interest in falconry than academics and joined the Southern California Falconry Club. In order to access falcon aeries located on cliff faces, Chouinard learned how to mountain climb, which immediately became his passion. ${ }^{17}$ After two years of community college and working part-time for his brother as a private detective, Chouinard taught himself how to blacksmith and began forging pitons (spikes used in climbing) in $1957 .{ }^{18} \mathrm{He}$ sold the first 
batches of pitons out of the back of his car in order to fund climbing expeditions; however, over time, he expanded the manufacturing to include carabineers and other small-form, metal-based climbing tools. By 1970, Chouinard Equipment was the largest supplier of climbing equipment in the United States and had developed a reputation for durability and quality. ${ }^{19}$

The company's move into apparel had humble and practical beginnings. According to Chouinard:

I bought myself a regulation team rugby shirt to wear, thinking it would make a great shirt for rock climbing. Overbuilt to withstand the rigors of rugby, it had a collar that would keep the hardware slings from cutting into my neck...Back in the States I wore it around climbing, and all my friends asked where they could get one. ${ }^{20}$

The initial addition of clothing to Chouinard Equipment's product set was seen as a way to support the existing equipment business, which despite topline success was still barely profitable, earning a 1 percent net income margin at best. ${ }^{21}$ The company’s apparel business was branded separately from Chouinard Equipment. Patagonia, named after South American region Chouinard and Tompkins had explored a few years earlier, was born in 1973, a silhouette of Mount Fitz Roy its $\log .^{22}$

Ironically, Patagonia, created as a secondary entity to the primary equipment business, grew to be the dominant of the two companies. Chouinard Equipment experienced legal trouble and ultimately filed for bankruptcy under Chapter 11 . The company was bought out by its employees, renamed Black Diamond, and resumed operations. ${ }^{23}$ Patagonia traveled a different path. Under the leadership of Kris McDivitt, who became Patagonia’s first titled CEO in 1979, the company boomed. Several innovations in outdoor apparel that consumers today view as commonplace were brought to market by Patagonia, including fleece clothing, bright colors 
(outdoor products had traditionally been tan or green), polyester long underwear, and the concept of wearing base-, mid-, and outer-layers. ${ }^{24}$ Sales grew from $\$ 20$ million to $\$ 100$ million during the 1980s, and the company expanded into Europe and Japan. ${ }^{25}$ By 2000, the company had $\$ 200$ million in net sales. ${ }^{26}$ By 2013, despite two recessions, revenues had grown to $\$ 600$ million. ${ }^{27} \mathrm{It}$ reached $\$ 800$ million by 2016. Throughout the decades of growth, Chouinard remained deeply involved in Patagonia's strategic and operational decision making, and, along with his wife, the sole shareholders of the company.

\section{Alternative Green Strategies}

\section{Doug Tompkins and Deep Ecology}

Doug Tompkins demonstrated his desire to promote environmentalism throughout his decades of managing Esprit. Early on, Esprit's corporate outings consisted of rafting trips led by the Tompkins's and listening to lectures given by environmental activists. ${ }^{28}$ In the late 1970 s and early 1980s, Tompkins's views on the state of conservation and sustainability became more pessimistic. He was influenced by the Norwegian philosopher and mountaineer Arne Naess, the founder of the "Deep Ecology" movement, who proposed viewing the world through a more disruptive lens. ${ }^{29}$ According to one journalist, "unlike the kind of environmentalism that supports technical fixes and 'business as usual,' deep ecologists hope to challenge values and practices in society—especially the overuse of technology and the fixation with economic growth.”30

By the late 1980s, Tompkins had become critical of his and his company's role in what he judged as an environmentally-destructive consumer culture. He initially sought change within Esprit through marketing. In a controversial campaign, Tompkins implored Esprit customers not to buy Esprit clothing. This "buy only what you need" strategy was supplemented by warning 
labels on clothing tags and designs with more muted, traditional colors to disincentivize excessive purchasing. ${ }^{31}$ Rather than attempt to bring further sustainability initiatives to Esprit, Tompkins decided instead to exit the corporate world entirely, selling all of his shares in Esprit in 1989. "I just realized,” Tompkins remarked, "what I was doing was making a lot of stuff that nobody needed and pushing a consumerist society. So I went to do something else." ${ }^{32}$ That "something else” resulted in his return to the Patagonia region of South America.

After leaving Esprit, Tompkins moved to a blighted 42,000 acre farm on the Reñihué fjord in southern Chile. ${ }^{33}$ His goal was to protect the plot of rainforest land from deforestation or encroachment from businesses and municipalities. Soon after, Tompkins began expanding his private landholdings by purchasing the surrounding acreage from willing sellers. Tompkins chose Chile for a variety of reasons. First, the rules for foreign investors were favorable and easy to understand. Second, buying land through his foundations in San Francisco allowed him to avoid paying taxes. Third, the area had very low population density—just 1.2 people per square kilometer — with land titles that were often in disarray. And finally, the region contained several tracts of ancient larch forests that could be purchased at a much lower price per hectare compared to land in Europe or North America. ${ }^{34}$

Tompkins established the Conservation Land Trust, endowing the fund with his personal capital and the charter of acquiring more land to build Pumalín Park. Tompkins and the man who would become his longtime attorney, Pedro Pablo Gutierrez, began to map out their buying strategy in 1991. For the most part, the land purchases Tompkins made were not unduly complicated: a small number of people held most of the land that interested him, and many of those landowners were not especially interested in the properties. ${ }^{35}$ Tompkins was a fair but 
steadfast negotiator, sticking to his offered price for months until vendors capitulated. ${ }^{36}$ From 1991 to 1998, the trust purchased close to 700,000 acres, 98 percent from absentee landowners. ${ }^{37}$

As time passed, Tompkins’s project became controversial and surrounded by rumors. By the end of 1993, Tompkins had become a major media topic in Chile as some of his largest purchases were poised for completion. The Chilean press questioned the "real” nature of his landacquisition efforts; anti-Semitic rumors circulated that Tompkins's park was ultimately meant as a haven for Jews, an accusation that even led to questioning by representatives from the Chilean government. ${ }^{38}$ Some hypothesized that Chileans’ growing rejection of Tompkins was perhaps a lasting consequence of the military dictatorship of General Pinochet (1973-1990), which had left a widespread suspicion in some parts of Chilean society of the new and foreign. In one observer's words: "No one could come to Chile and buy such a great piece of land so close to the frontier with Argentina for love of nature alone.»39

Legislators and the press also complained that Tompkins was pushing poor Chileans, many of whom were barely making a living, off of their land. At times, landowners who accepted money in exchange for their plots quickly bankrupted themselves, then cast Tompkins as the villain. ${ }^{40}$ Though Tompkins was quick to defend the legality of his actions and to assert that his intentions were good, public opinion against him mounted. As recounted by journalist Andrés Azócar:

The businessman's efforts to move closer to the community were like tiny boats rowing against the current, and in different directions. The huge number of letters that Tompkins...sent to the newspaper "El Llanqihue" was irrelevant. In them, he tried to explain and repeat that most of the settlers moved to other lands acquired by the businessman in the area-even though they were not entitled to - that he had no intentions of cutting Chile in two, that his park would not restrict access to the public, [and] that he was not in favor of depopulating Palena... ${ }^{41}$ 
Tompkins's relationship with the Chilean government evolved over time. Under the government of Eduardo Frei Ruiz-Tagle (1994-2000) relations were difficult. Frei’s government tracked Tompkins's activities for five years in efforts to find grounds to remove him from Chile, but found nothing Tompkins did was even on the margins of illegality. ${ }^{42}$ Ultimately, Tompkins and the government reached an agreement to designate Pumalín as a nature sanctuary to be run by an independent foundation. ${ }^{43}$ After holding the land privately for 15 years, on August 19, 2005, Pumalín Park was formally designated a Nature Sanctuary by the president of Chile, and control of its acreage was handed over to Fundación Pumalín, a Chilean foundation. ${ }^{44}$

Tompkins's improved government relations may have resulted from his employment of Enrique Correa, a former member of Chilean government, as a lobbyist. ${ }^{45}$ The role of Kris McDivitt, the first CEO of Patagonia, who married Tompkins in 1993, was also important. McDivitt was savvier in terms of interpersonal relations and public relations than was Tompkins. She brought containers of Patagonia clothes for employees, followed their lives, and engaged in many other activities that reduced hostility among the people around Tompkins's foundation. ${ }^{46}$ According to one of Tompkins's colleagues, "she made him evolve, she humanized him, [and] she turned him into a landholding environmentalist who could also worry about other people.”47 The two executed a large-scale strategy to acquire massive amounts of land for conservation, preservation, and eventual repatriation in several wildlife zones beyond the Pumalín sanctuary. As of 2016, the Conservation Land Trust-in conjunction with McDivitt's organization, Conservacion Patagonica ${ }^{48}$ — had formed 10 national parks in Argentina and Chile, encompassing over two million acres. (see Table 1) As described by The Atlantic: “The [Tompkins's] have purchased enough land in Chile and Argentina to equal an area the size of nearly two Rhode 
Islands, and they plan to donate these [lands] to the respective governments in the form of national parks. They have protected more land than any other private individuals in history.”49

Table 1: Selected national parks in Argentina and Chile created/expanded by the Conservation Land Trust

\section{$\underline{\text { Park }}$}

Corcovado National Park

Pumalín Park

Patagonia National Park

Iberá Park

Yendegaia National Park

El Impenetrable National Park

Monte León National Park

Cabo León

El Rincón

El Piñalito Provincial Park

El Cañi Sanctuary
Size (thousand hectares) Country

293.8 Chile

289.4 Chile

259.0 Chile

161.9 Argentina

149.7 Chile

128.0 Argentina

66.8 Argentina

26.3 Chile

15.2 Argentina

3.8 Argentina

0.5 Chile

Source: The Conservation Land Trust; The Cat Survival Trust; Conservacion Patagonica

While most noted for these land purchases in South America, Tompkins also engaged in further environmentalism through the Foundation for Deep Ecology (FDE), which he founded in 1990. In a 20-year span, the FDE published over 20 books, reports, and advocacy campaigns to raise awareness of environmental issues in the United States. The FDE also made strategic grants to nonprofit organizations protecting the environments of Chile and Argentina. By 2012, more than $\$ 52$ million had been donated to over 1500 organizations. ${ }^{50}$

Patagonia's Green Capitalism 
Patagonia's commitment to the environment dates back to the early days of Chouinard Equipment. In 1970, Chouinard realized that steel pitons-the staple product of Chouinard Equipment—were scarring Yosemite and other mountains as more and more climbers hammered the pitons into the rock face. Rather than slowly phase out pitons, easing the hit on topline sales, Chouinard Equipment immediately stopped selling the product. Concurrently, the company introduced aluminum chocks, which served the same function as pitons without damaging the natural rock surface. In its first catalog, Chouinard Equipment published an article espousing the philosophy of “clean climbing,” climbing without leaving a trace on the environment. ${ }^{51}$

As Patagonia scaled, it began donating every year to small non-profits devoted to habitat restoration. This program was formalized in 1986 when the company created the policy of annually donating ten percent of profits to environmentally-focused organizations; that metric was later raised to one percent of sales. ${ }^{52}$ By 2016, the company’s donation program had granted $\$ 70$ million to grassroots activists. ${ }^{53}$ Patagonia also began making incremental changes to its internal operation to be more environmentally-friendly. Catalogs were printed on recycled paper, and R\&D dollars were spent on developing recycled polyester. ${ }^{54}$

From 1991 to 1994, Patagonia took a deep dive to understand and map the full environmental impact of its supply chain, focusing in particular on the damage caused by using its four main inputs: cotton, wool, polyester, and nylon. In the words of Rick Ridgeway, VP of Public Engagement at Patagonia and lifelong friend of both Tompkins and Chouinard:

We mapped our supply chain much more thoroughly than our competitors. [We made] direct relationships with the secondary and tertiary companies in that chain, including mills and dye houses and extending to a farm and fiber production level. ${ }^{55}$ 
Based on this analysis, Patagonia began making jackets out of recycled polyester and moved to organically-grown cotton in 1996, despite the sourcing change "tripling the company’s supply costs." ${ }^{56}$ In 1998, ignoring customer demands for the technology, anti-odor chemicals were eliminated given concerns related to the chemicals' impact on the environment. ${ }^{57}$

Patagonia’s philosophy of “cause no unnecessary harm” led over time to more campaigns that conflicted with the mindset of traditional retail businesses. In 2004, Ridgeway brought the idea of implementing Tompkins’s "buy only what you need” marketing strategy to Patagonia. "It took years to get the ads approved and everybody on board," recalled Ridgeway, but now "asking customers not to buy a new product until they need it fits our business model." ${ }^{\text {58 }}$ Famously, on Black Friday 2011, the largest shopping day of the year, Patagonia took out a full page advertisement in the New York Times that boldly stated “Don’t Buy This Jacket.”59

In support of the “Don’t Buy This Jacket” campaign, Patagonia also rolled out its Worn Wear program. The company began offering repair services to extend the life of its products, while also volunteering to recycle used Patagonia clothing on its customers' behalf. The program has grown in size to 40,000 repairs per year handled by a full-time staff of 45 repair technicians, including a team that tours the country in an RV repairing and recycling clothing on location. ${ }^{60}$ In the words of Ridgeway, “it’s a loyalty program that doesn't inspire more purchases; it turns loyalty on its head.” 61

Patagonia's green strategies have more recently evolved beyond apparel. Patagonia Provisions, launched as a new company in 2013, aimed to change the food industry. The startup invests in bringing to market sustainably-sourced food products including salmon, bison jerky, and organic soups, and advocating for agricultural techniques that have the ability to reduce water 
consumption, regenerate depleted soil, and stop-if not reverse-the industry's deleterious impact on climate change. While a nascent effort, the environmental impact on revolutionizing farming and food production had potential to be significantly greater than that of the eco-friendly initiatives promoted by Patagonia’s apparel business, especially with regard to reducing carbon emissions and increasing carbon sequestration. In 2016 Chouinard assessed it as "the most important project the company has ever tackled.”62

\section{Comparative Environmental Impact}

A comparison of the environmental impact of Tompkins's deep ecologism and Chouinard's green capitalism is inherently subjective given the lack of a standardized measurement rubric. We lack a methodology to compare the value of preserving an acre of wetland with extending the life of a fleece jacket by three years. (On the latter point, Patagonia estimates extending the use of clothing nine months results in a 20 to 30 percent reduction in

related waste. ${ }^{63}$ ) The following sections provide crude quantitative estimates around Tompkins's and Chouinard's environmentalism in order to open a discussion concerning how best to compare the two approaches and identify their tradeoffs.

\section{Evaluating the benefit of Tompkins's land purchases}

The Tompkins's, through their organizations and personal endowment, helped protect roughly 1.5 million hectares in South America. This vast acreage-replete with forests, grasslands, and wetlands—slows the adverse effects of climate change through biomass's storage and sequestering of carbon. According to one expert scientist, the soil and vegetation of Tompkins's protected areas may store anywhere from 30 to 60 tons of carbon per hectare, depending on the topography of the land. In addition, previously-degraded and carbon-depleted 
lands that are restored by Tompkins Conservation may restart sequestering carbon from the atmosphere at anywhere from 1.5 to 3 tons per hectare per year. ${ }^{64}$ Based on rough assumptions regarding topographical make up, the total sink capacity of Tompkins's sanctuaries-i.e. the amount of carbon that can be stored—approximates 80 million tons of carbon at equilibrium. See Table 2. In addition, it is important to note, by protecting these habitats indefinitely, Tompkins prevented the future emission of the lands' stored carbon that would have occurred via continued environmental destruction.

Table 2: Estimated impact of Tompkins's protected areas on atmospheric $\mathrm{CO}_{2}$

\section{Assumptions}

Tons of carbon sequestered per year per hectare (forests) Tons of carbon sequestered per year per hectare (grasslands) 1.5

Tons of carbon sequestered per year per hectare (wetlands) 3.0

Tons of carbon stored per hectare in equilibrium (forests) $\quad 55.0$

Tons of carbon stored per hectare in equilibrium (grasslands) 35.0

Tons of carbon stored per hectare in equilibrium (wetlands) 60.0

Hectares protected $\quad 1,500,000.0$

Assumed percentage of forest land $\quad 50 \%$

Assumed percentage of grasslands $\quad 25 \%$

Assumed percentage of wetlands $\quad 25 \%$

\begin{tabular}{|c|c|}
\hline Total carbon sink capacity (tons) & $76,875,000.0$ \\
\hline
\end{tabular}

Sources: author estimates; Telephone interview with Professor Rattan Lal, October 62016.

It is more challenging task even to guestimate the environmental impact of Tompkins's preservation was the protection of the habitats of many of Patagonia's threatened or endangered species. Restoring lands that had previously been used for raising livestock, logging, or other business purposes rebuilt the natural environment for dislocated species. Iberá Park hosts more 
than 360 species of birds and serves as a massive source of fresh water for Northeast Argentina. ${ }^{65,66}$ Corcovado National Park—along with providing sanctuary to seals, sea lions, and penguins - has been described as a “crucial nursery area for blue whales.” 67 Conservación Patagónica, an organization launched by Kris Tompkins in 2000 and part of the umbrella of the family's collective environmental organizations, is actively involved in recovery programs for nine at risk species within the Patagonia region. ${ }^{68}$ There is no current metric or methodology which enables a quantitative estimate of the environmental benefits of saving and protecting animal species, despite their known key role of many species in sustaining entire environmental eco-systems. It is equally hard to capture the social and environmental externalities generated by Tompkins. For example, he believed protecting the land would have an enormously positive longterm economic impact on regional tourism, and went so far as to build and establish tourismspecific infrastructure in Iberá.

Despite the sharp rise in awareness of global warming over the last decade, there are no tools to capture the value of uncompromised natural habitats. The net present value of new ventures that require incremental deforestation are probably negative when accounting for the long term environmental costs and not just the immediate economic gains. Tompkins spoke to this under-appreciation of biodiversity loss in one of his early treatises on the rationale for buying rainforests:

Compromises on ancient forests are never compromises; they are losses...Ecological concerns are long term; transnational concerns are narrow and short term, exploitive and rarely aimed at preserving integrity and diversity of natural systems. The social justice arguments of jobs versus wilderness always surface-again, short-term thinking versus long-term. ${ }^{69}$ 
Tompkins's approach adds value, then, by forcing long-term perspectives onto a society that, certainly since the rise of shareholder capitalism models in the United States and elsewhere from the 1980s, has mostly over emphasized single-stakeholder and short-term results. ${ }^{70}$

\section{Evaluating Chouinard's business choices and advocacy}

Several of Patagonia's internal business initiatives can be measured and are made public by the company. Although the nature and limitation of environmental reporting is a topic and active scholarly debate, ${ }^{71}$ it would be churlish not to recognize Patagonia's self-assessment of the impact of its environmental programs since their inception. These initiatives are only a sample of the many changes Patagonia has implemented since the mid-1980s:

Table 2: Selected examples of Patagonia environmental initiatives and impact

Initiative
Renewable energy use
Employee Drive-Less program
$1 \%$ for the planet
Product recycling
\$20 million and change fund
Sourcing
Patagonia denim

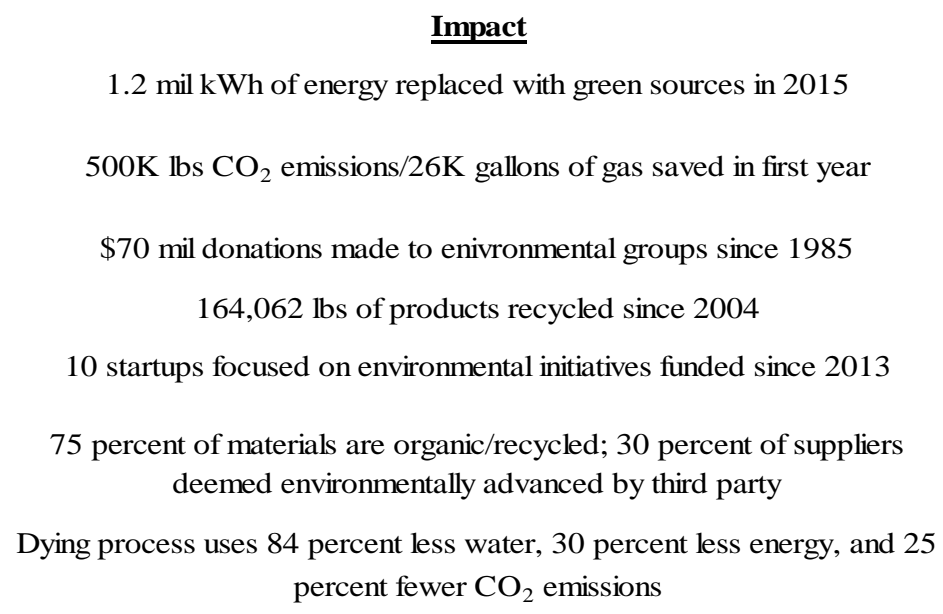

Source: Patagonia Environmental + Social Initiatives Annual Report 2015

Beyond the company-specific actions taken by Patagonia, the company has also pursued active advocacy supporting environmental causes. The impact of this advocacy is hard to measure beyond giving individual, and in the language of social science anecdotal, examples. Patagonia has partnered, for example, with several firms to launch new organizations dedicated to fighting 
climate change. For example, in 2002 the company co-launched 1\% for the Planet, a non-profit dedicated to expanding Patagonia's pledge of donating a one percent of gross revenue every year to environmental groups. Twelve hundred companies are now members and have donated in excess of $\$ 100$ million to over 3,300 different non-profits. ${ }^{72}$

The company has also served as an outside consultant and role model to firms trying to change their own operations to be more sustainable. Wal-Mart enlisted Patagonia's help in piloting changes that reduced water consumption and packaging waste; Levi Strauss utilized Chouinard's supply chain benchmarking to help save 45 million gallons of water annually through more environmentally-friendly production. ${ }^{73}$ Patagonia has pioneered and shared standards and methods for incorporating environmental costs into traditional accounting statements. According to Ridgeway, "we have tools that measure footprints and that allow designers to understand the environmental impact of their design choices. ${ }^{\text {} 74}$ Chouinard's and Ridgeway's advocacy has even reached Harvard Business Review; the two co-authored an article promoting retail-wide rating of products according to measured environmental and social impact. ${ }^{75}$

\section{Trade-Offs}

Absent an advance in current methodologies and environmental metrics, there is no sensible way to quantify and compare the overall environmental impact of protecting Patagonian habitats versus promoting sustainable manufacturing practices. However it is useful to identify a number of trade-offs in both strategies.

Two significant issues arise from Tompkins's land-buying strategy. First, Tompkins individually determined the optimal use of the land based on his own views, not those of the surrounding communities. Although this might be considered the norm in governance of private 
property, both the scale of the purchases and his status as a foreigner might give pause for concern. Certainly Tompkins legally purchased his acreage, buying from landowners who were willing to sell at a fair price. Yet even Antonio Horvath, a Chilean senator who had been known for his support of environmental causes, took issue with Tompkins non-consultation with Chilean stakeholders. Horvath viewed the scale of Tompkins's landholdings and his unchecked power to do what he wished with that land as "a blow to sovereignty, to territorial continuity."76

This excessively paternalist aspect of Tompkins's strategy was illustrated by his remodeling of the local villages located on or next to his preservations. Quoting an article from The Atlantic:

Tompkins has also beautified the homes of the neighbors, as well as the town's gas station, school, supermarket, and bus shelters. "The people were a little hesitant. A gringo shows up and tells us our town is ugly?”...Tompkins has taken many of the decisions about the design of these renovations into his own handsthe patterns of the houses' trim, the colors of their fences. ${ }^{77}$

While some villages reacted with bemused acceptance to Tompkins's design overhaul, others reacted with resentment. As one local citizen described:

It bothers me that they call it the Patagonia Park because there's no Patagonian identity in it. You see the buildings and it looks like you're in London! It's the same in Amarillo — what they did to the houses there. It's not Patagonian. It looks like you're in Germany. ${ }^{78}$

In many ways, Tompkins fits the mold of American philanthropy since Andrew Carnegie, the steel magnate who created the first US philanthropic foundation before World War $1 .^{79}$ Carnegie similarly appointed himself the best-suited person to allocate his own philanthropic dollars by funding university, library, and arts establishments as he saw fit, although his reshaping of the world was done in the country of which he was a citizen. In both instances, wealthy men 
were investing in areas they deemed undervalued by society. Tompkins felt compelled to buy as much land as possible because he believed neither businesses nor governments could be trusted to respect the Patagonian wilderness. In this individual episode, the environmental benefits may have been considerable, but the precedent of individual rich people being able to reshape landscapes without the support or consultation of any stakeholder beyond the willing sellers of property had as much potential for adverse than positive environmental outcomes.

Indeed the alignment between a philanthropist wanting to do good and the society in which they execute their plan is thoroughly contested. The controversy over the philanthropy of Roxanne Quimby - co-founder of the Burt's Bees personal care company — provides a recent example. In 2016, Quimby, when attempting to donate $\$ 100$ million of land and facilities to create a new national park in Maine, was met with fierce hostility. As detailed in the Washington Post:

[Quimby's] effort has bitterly divided this corner of New England...residents in towns near the proposed park voted against its creation, the governor and legislature are opposed and Maine's congressional delegation [refused] to introduce the measure necessary to create a national park. That [left] only the prospect of President Obama using his authority under the Antiquities Act of 1906 to declare the land a national monument... "It has nothing to do with us anymore," [Millinocket resident] Lorri Haskell said..."it has to do with whether President Obama is going to betray us. Is this how democracy works?”80

The execution of a vision such as that of Tompkins is of major importance in any overall assessment of impact. One of the key tenets of Tompkins's philosophy was the fact that his ownership of the land was meant to be temporary. As he outlined in an early editorial:

Our feeling is that land purchases must be seen as interim emergency or preemptive measures only. Within a reasonable time (probably 10 to 20 years) transfer of those purchases should be made to return those lands back to the public commons. ${ }^{81}$ 
As the list of national parts in Table 1, this strategy was implemented. From this perspective, Tompkins can be absolved from Naomi Klein’s critique of "green billionaires” whose rhetoric was not matched by measurable reality. ${ }^{82}$

Tompkins's investment in conversation is not easily scalable. However his application of entrepreneurial capabilities and ability to assemble resources to a major environmental issue might well be scalable.

The Patagonia strategy was also not without trade-offs and limitations. Although Patagonia was an innovator in corporate sustainability, the company continues to thrive off of a consumer culture that is inherently wasteful in environmental terms. That the company has tripled sales since the early 2000s runs counter to Chouinard's stated goal of moderated and sustainable growth, and suggests that the Worn Wear program and anti-consumerism advertisements are not delivering paradigm shifts. In fact, the "Don’t Buy This Jacket” campaign worked to boost Patagonia sales. While the company would claim that growth came from taking market share, it is impossible to quantify how many consumers truly needed a new jacket versus those that bought a new jacket having been inspired by the advertisements. As said by journalist J.B. Mackinnon:

It's quite possible that Patagonia's philosophy has attracted many shoppers to the brand without deeply affecting their buying habits, as suggested by the way that "Don’t Buy This Jacket” translated, for many, into "Buy This Jacket."

The company, despite its environmental and social efforts, at times ran into situations in which delivering on its mission to "build the best product" conflicted with the eco- and sociallyconscious priorities that Patagonia simultaneously stood for. In 2011, an internal audit discovered “multiple instances of human trafficking, forced labor, and exploitation in Patagonia’s supply chain." ${ }^{84}$ In 2016, Greenpeace, testing a wide variety of outdoor apparel of different brands, found 
several Patagonia samples that contained hazardous polyflourinated chemicals. ${ }^{85}$ Patagonia confirms on its website that the components in its technical shell jackets are potentially harmful. The company states:

The nylon and polyester polymers we use in our technical shells — which we also use in some of our other products - are neither infinite nor sustainable and the DWR (durable water repellent) finish we apply to our technical shells is potentially toxic to the environment... we've tried all sorts of alternatives to fossil fuel-based shell fabrics by developing fabrics from recycled polyester. But recycled nylon is still less durable, heavier, and harder to obtain in quantity-so we still find ourselves relying on virgin nylon for its durability. ${ }^{86}$

Patagonia is willing to make this tradeoff in order to ensure durability. As Ridgeway states:

Durability becomes the main environmental component of a product...If we replace our current water resistant chemistry with what Greenpeace advocates, then durability goes way down so the product has to be replaced more frequently causing more harm than what we currently offer. ${ }^{87}$

Certainly, there are some buyers who value the longevity of Patagonia gear and will replace that equipment only when necessary. However, there are other consumers who are more fashion- and tech-driven, willing to replace last year's jacket for today's version. For those customers, Patagonia's choice to use more toxic components may not, in practice, have an impact on the frequency of product replacement. However, if consumers are willing to discard Patagonia's products well before the products themselves wear out-i.e. if consumer preference and not true durability ultimately dictates a product's replacement cycle-then the rationale for using lesseco-friendly components is undermined. The most that can be said is that Patagonia's presence in the apparel market affords consumers the ability to vote for more eco-friendly alternatives by buying the firm's products. 
Patagonia's strategy had an evident scalability - far more so than the specific Tompkins strategy of buying huge amounts of land for conservation. The supply chain initiatives that lower waste, save water, and reduce emissions can be and have been adopted by other companies. Environmental accounting standards that Patagonia created have been adopted by some other companies, both as a way to measure true cost but also as a mechanism for making operations more efficient. Finally, the internal capital earned by Patagonia is exercising can have a sustained multiplier effect through its ongoing support of new grassroots startups, either via grants from Patagonia's one percent donation pledge or as seed investments by Patagonia's recently-launched “\$20 Million \& Change” venture capital fund.

Patagonia's systematic and detailed approach to mapping out and tracing the footprint of its products has usefully exposed the often unsustainable and unethical components of the textile manufacturing industry as a whole. The company has worked to improve its supply chain, often going beyond required guidelines to serve as a model for how an apparel operation can and should be managed. As The Atlantic explains:

The status quo throughout the industry...largely requires that companies only look at and remedy labor trafficking issues at their first-tier suppliers. In attempting to monitor and improve the treatment of its second-tier-factory workers, Patagonia is going far beyond that standard. ${ }^{88}$

Importantly, Patagonia has set a valuable precedent by being transparent with its own failings. Rather than hide the fact that some of the company's second- and third-tier Taiwanese suppliers were using exploited labor, Patagonia went public. In the words of Ridgeway:

I was in the meeting when we found out from auditors that we had slave labor in our supply chain. What are we going to do? First thing that came out was we have to go public. We have to tell people about the problem. We have to get supply chain involved. We have to get government involved. You can’t fix a system 
problem without all players in the system coming together. That is our default reaction. ${ }^{89}$

By shining a public light on grey areas of the apparel industry's supply chain that no firm had yet investigated, and working with companies and governments to address those issues, the company has promoted system-wide change by implementing solutions to problems that other companies, and consumers, had not identified, or chose to ignore.

Yet doubts remain on the extent to which Patagonia has served as a role model. It is still widely believed that the pursuit of environmental and social sustainability comes with a trade-off on bottom line profitability. Patagonia's evident achievements in successful brand-building serves as a compelling counter-example. Yet because Patagonia's sole shareholder is the Chouinard family, the company has more flexibility than a publicly-traded member of the Fortune 500 mandated to report quarterly returns. A key issue, then, is how far public companies have really learned from Patagonia.

Evidently the willingness of large companies to partner and work with Patagonia reflects their considerable interest in understanding the secrets of combining sustainability with profitability. The extent to which the company has functioned as a role model is less clear. In a 2016 interview, Chouinard recalled that his response when Tompkins urged him to follow his own example, he would say that his aim was "to change the way people do business. I can do far more by showing an example.” However he went on to comment on his work with large companies:

"They took the low-hanging fruit, recycling plastic, converting their fleet over to natural gas. Things like that. They did everything that ends up making 'em more money. But when it comes down to doing the hard things, anything with a long-term payoff, they backed out...All of these companies, whether it's Dannon or Unilever, they're all greenwashing. They start out making a 
big deal out of something and they back down. It's like Nike started out doing a little bit of organic cotton, like 1 percent. Now I don't know if they do any at all. The fashion industry, same thing." 90

Chouinard's accusations of greenwashing by specific firms evidently must be regarded entirely as his personal value judgement. However his broad argument is broadly aligned with studies suggesting that many high profile sustainability campaigns by some large companies are primarily strategies to boost bottom line profitability by reducing supply chain costs. Such strategies, one study suggested, "is fundamentally aiming for sustainability of big business, not sustainability of people and the planet."91

\section{Conclusion}

This working paper has suggested that both the Chouinard and Tompkins strategies bring positive environmental benefits but with trade-offs and limitations. By trying to improve the apparel system as a member of that system, Patagonia continues to incorporate system-wide downsides. Its customer promise to provide the highest-quality outdoor products requires Patagonia to sell goods that are not 100 percent organic, recycled, or resource-neutral in order to prioritize durability and reduce replacement. Sourcing from developing countries—more or less a mandatory element of any apparel business in today's economy-exposes the company to the risk of working with counterparties that exploit their workforce. The vision was that as the company constantly improved its operations, shared its knowledge, and thrives as a brand, it would become a role model. Patagonia has certainly been studied by high-profile large firms, but it remains the extent to which large public companies have yet replicates the parts of the Patagonia sustainability strategy which involve more than achieving greater cost-efficiency. This might be because a longer time horizon is needed to make a full assessment. 
The Tompkins strategy might be seen as one-off and quixotic, and excessively paternalistic, but its positive environmental impact should also be recognized. The estimated sequestering and storage of 80 million tons of carbon is significant in terms of halting the pace of climate change. When that is combined with other environmental gains which cannot be quantified at all, such as saving species from extinction, the net positive environmental impact is greater still. As in the case of Patagonia, Tompkins also engaged in considerable environmental advocacy which must also be seen as a major benefit for the natural environment, even if one which once again there are no metrics to satisfactorily capture the importance of such public voice. The natural environment would clearly benefit from a combined Tompkins/Chouinard approach on pollution and environmental destruction by actors not seeking their commercial exploitation. However the broader take-away from the comparison of these two individuals might be the positive potential for the application of entrepreneurial strategies and capabilities beyond seeking to for-profit businesses more sustainable. Conservation is only one avenue in which this approach could be adopted.

\section{Endnotes}

${ }^{1}$ The authors would like to thank Mike Toffel for his insightful comments on an earlier draft of this working paper, Annelena Lobb for invaluable research assistance, and the Division of Research and Faculty Development at the Harvard Business School for its support.

${ }^{2}$ Caty Enders and Jonathan Franklin, "Doug Tompkins: life and death of the ecological visionary behind North Face," The Guardian, December 13, 2015, http://www.theguardian.com/usnews/2015/dec/13/douglas-tompkins-co-founder-north-face-chile-conservation, accessed March 1, 2016. 
${ }^{3}$ John Elkington with Tom Burke, The Green Capitalists (London: Victor Gollancz, 1987).

${ }^{4}$ John Elkington, Cannibals with Forks: the Triple Bottom Line of 21st Century Business (Oxford: Capstone Publishing, 1997).

${ }^{5}$ For an introduction to this literature, see Pratima Bansal and Andrew J. Hoffman (eds.), The Oxford Handbook of Business and the Natural Environment (Oxford: Oxford University Press, 2012).

${ }^{6}$ Robert Isaak, “Globalization and Green Entrepreneurship,” Greener Management International, 18, (1997), pp. 80-90; Michael Lenox and Jeffrey G. York, “Environmental Entrepreneurship”, in Bansal and Hoffman (eds.) Oxford Handbook, pp. 70-82; Michael Schaper (ed.), Making Ecopreneurs: Developing Sustainable Entrepreneurship (Ashgate: Aldershot, 2005).

${ }^{7}$ Paul Hawken, The Ecology of Commerce (New York: HarperCollins, 1993); Paul Amory Lovins and L. Hunter Lovins, Natural Capitalism: Creating the Next Industrial Revolution (Boston: Little, Brown and Company, 1999).

${ }^{8}$ Robert Isaak, Green Logic: Ecopreneurship, Theory and Ethics (Greenleaf: Sheffield, 1998).

${ }^{9}$ Liz Walley and David W. Taylor, "Opportunists, Champions, Mavericks ...A Typology of Green Entrepreneurs,” in Schaper (ed.), Making, pp.27-42.

${ }^{10}$ Geoffrey Jones, Profits and Sustainability. A History of Green Entrepreneurship (Oxford: Oxford University Press, 2017; Hartmut Berghoff and Adam Rome (eds.) Green Capitalism? Business and the Environment in the Twentieth Century (Philadelphia: University of Pennsylvania Press, 2017).

${ }^{11}$ Daniel Duane, "Rebel With a Cause: Yvon Chouinard on the Passing of His Lifelong Friend, Doug Tompkins,” Men’s Journal, http://www.mensjournal.com/adventure/races-sports/rebel- 
with-a-cause-yvon-chouinard-on-the-passing-of-his-lifelong-friend-doug-tompkins-20160106, accessed March 1, 2016.

${ }^{12}$ Tina Grant (ed.), International Directory of Company Histories, Volume 29, (Farmington Hills, MI: St. James Press, 2000), pp. 178-181.

${ }^{13}$ Duane, "Rebel.”

${ }^{14}$ Grant, International Directory.

${ }^{15}$ Ibid.

${ }^{16}$ Duane, "Rebel.”

${ }^{17}$ Yvon Chouinard, Let My People Go Surfing, (New York, NY: The Penguin Press, 2005), p. 11.

${ }^{18}$ Ibid., p. 15.

${ }^{19}$ Ibid., pp. 25, 31.

${ }^{20}$ Ibid., p. 35.

${ }^{21}$ Ibid., p. 30.

${ }^{22}$ Ibid., p. 38.

${ }^{23}$ Ibid., p. 65.

${ }^{24}$ Ibid., pp. 52-54.

${ }^{25}$ Forest Reinhardt, Ramon Casadesus-Masanell, and Hyun Jin Kim, "Patagonia," Harvard Business School Case No. 711-020 (Boston, MA: Harvard Business School Publishing, rev. October 10 2010), p. 2.

${ }^{26}$ Ibid., p. 2.

${ }^{27}$ Drake Baer, “How Patagonia's New CEO Is Increasing Profits While Trying To Save The World,” Fast Company, February 28, 2014, http://www.fastcompany.com/3026713/lessons- 
learned/how-patagonias-new-ceo-is-increasing-profits-while-trying-to-save-the-world, accessed March 11, 2016.

${ }^{28}$ Diana Saverin, “The Entrepreneur Who Wants to Save Paradise,” The Atlantic, September 15, 2014, http://www.theatlantic.com/business/archive/2014/09/the-entrepreneur-who-wants-tosave-paradise/380116/, accessed March 192016.

${ }^{29}$ Ibid.

${ }^{30}$ Ibid.

${ }^{31}$ Grant, International.

${ }^{32}$ Caty Enders and Jonathan Franklin, “Doug Tompkins: life and death of the ecological visionary behind North Face," The Guardian, December 13, 2015, http://www.theguardian.com/usnews/2015/dec/13/douglas-tompkins-co-founder-north-face-chile-conservation, accessed March 1, 2016.

${ }^{33}$ Tompkins Conservation, “Milestones,” http://www.tompkinsconservation.org/milestones.htm, accessed April 14, 2016.

${ }^{34}$ Andrés Azócar Zamudio, Tompkins: El Millonario Verde (Editorial La Copa Rota S.A.: Santiago, 2007), p. 110.

${ }^{35}$ Ibid, p. 115.

${ }^{36}$ Ibid, p. 116.

37 Pumalín Park and Project, "Pumalín's History,” http://www.parquepumalin.cl/en/pumalin_history.htm, accessed April 2, 2016.

${ }^{38}$ Azócar Zamudio, Tompkins, p. 80-83.

${ }^{39}$ Ibid, p. 174.

${ }^{40}$ Ibid, pp. 127-128, 130. 
${ }^{41}$ Ibid, p. 176.

${ }^{42}$ Ibid, p. 178.

${ }^{43}$ Ibid, pp. 269-270.

${ }^{44}$ Ibid.

45 Ibid, pp. 208-210.

${ }^{46}$ Ibid, p. 144.

${ }^{47}$ Ibid, p. 146.

48 Conservacion $\quad$ Patagonica, "Our $\quad$ History,” http://www.conservacionpatagonica.org/aboutus_oh.htm, accessed August 29, 2016.

${ }^{49}$ Saverin, "The Entrepreneur."

50 Foundation For $\quad$ Deep Ecology, "Grantmaking," http://www.deepecology.org/grantmaking.htm, accessed April 13, 2016.

${ }^{51}$ Jena Ball, "Patagonia Clothing: Making a Profit and Meeting Environmental Challenges," Mother Earth News, December 2009/January 2010, http://www.motherearthnews.com/natureand-environment/patagonia-clothing-zmaz09djzraw.aspx, accessed April 1, 2016.

${ }^{52}$ Chouinard, Let, p. 61.

53 Patagonia, "Our Business and Climate Change," http://www.patagonia.com/us/patagonia.go?assetid=112453, accessed April 14, 2016.

${ }^{54}$ Chouinard, Let, p. 63.

55 Telephone Interview with Rick Ridgeway by Ben Gettinger, April 4, 2016.

${ }^{56}$ Seth Stevenson, “Patagonia's Founder Is America's Most Unlikely Business Guru,” Wall Street $\begin{array}{llll}\text { Journal } & \text { Magazine, } & \text { 26, }\end{array}$ 
http://www.wsj.com/articles/SB10001424052702303513404577352221465986612, accessed April 2, 2016.

${ }^{57}$ Reinhardt, Casadesus-Masanell, and Kim, “Patagonia,” p. 3.

${ }^{58}$ Telephone Interview with Rick Ridgeway.

59 Tim Nudd, “Ad of the Day: Patagonia," Adweek, November 28, 2011, http://www.adweek.com/news/advertising-branding/ad-day-patagonia-136745, accessed April 11, 2016.

60 Patagonia, “Worn Wear: Better Than New," http://www.patagonia.com/us/worn-wear, accessed April 8, 2016.

${ }^{61}$ Telephone Interview with Rick Ridgeway.

${ }^{62}$ Chouinard, Let, pp. 221-225.

${ }^{63}$ Patagonia, 2015 Annual Report: Environmental + Social Initiatives (Ventura, CA: Patagonia, 2015), p.15.

${ }^{64}$ Telephone interview by Ben Gettinger with Professor Rattan Lal, Director of the Carbon Management and Sequestration Center, Ohio State University, Columbia, Ohio, October 6, 2016. 65 The Conservation Land Trust, "Iberá Park," http://www.theconservationlandtrust.org/eng/ibera.htm, accessed May 14, 2016. ${ }^{66}$ Telephone interview with Rick Ridgeway by Ben Gettinger, August 15, 2016. 67 The Conservation Land Trust, "Corcovado National Park," http://www.theconservationlandtrust.org/eng/corcovado.htm, accessed May 2016. 68 Parque "Threatened Patagonia, Species," http://www.patagoniapark.org/threatened_species.htm, accessed May 8, 2016.

${ }^{69}$ Douglas Tompkins, “Why buy rainforests?” Buzzworm 4, (January-February 1992), p. 16. 
70 For a recent review of the contingency of shareholder capitalism, which notes the prevalence of stakeholder capitalism even in the United States before the 1980s, see Brian Cheffins, “The Team Production Model as a Paradigm,” 38 (2015), pp. 397-432. See also Geoffrey Jones, "Debating the Responsibility of Capitalism in Historical and Global Perspective, "Harvard Business School Working Paper, No. 14-004, July 2013.

${ }^{71}$ Christopher Marquis, Michael W. Toffel, and Yanhua Zhou, "Scrutiny, Norms, and Selective Disclosure: A Global Study of Greenwashing,” Organization Science, 27:2 (March-April 2016), pp. 483-504.

72 1\% for the Planet, “History,” http://onepercentfortheplanet.org/about/history/, accessed August 192016.

73 Stevenson, "Patagonia's Founder.”

74 Teleephone Interview with Rick Ridgeway by Ben Gettinger, April 4, 2016.

75 Yvon Chouinard, Jib Ellison, and Rick Ridgeway, “The Sustainable Economy,” Harvard Business Review, October 2011, https://hbr.org/2011/10/the-sustainable-economy, accessed May 14, 2016.

${ }^{76}$ Azócar Zamudio, Tompkins, p. 140.

${ }^{77}$ Saverin, “The Entrepreneur.”

78 Ibid.

${ }^{79}$ Oliver Zunz. Philanthropy in America: A History (Princeton, NJ: Princeton University Press, 2012).

${ }^{80}$ Brady Dennis, "Proposed national park is a multimillion-dollar gift wrapped up in distrust," The Washington Post, May 22, 2016, https://www.washingtonpost.com/national/healthscience/proposed-national-park-is-a-multimillion-dollar-gift-wrapped-up-in- 
distrust/2016/05/22/0f036aa0-1d0b-11e6-b6e0-c53b7ef63b45_story.html, accessed September 18, 2016.

${ }^{81}$ Tompkins, “Why buy rainforests?”

${ }^{82}$ Naomi Klein, The Changes Everything. Capitalism vs. The Climate (New York: Simon \& Schuster, 2014), chapter 7.

83 J.B. Mackinnon, "Patagonia's Anti-Growth Strategy," The New Yorker, May 21, 2015, http://www.newyorker.com/business/currency/patagonias-anti-growth-strategy, accessed April 13, 2016.

${ }^{84}$ Gillian B. White, “All Your Clothes Are Made With Exploited Labor,” The Atlantic, June 3, 2015, http://www.theatlantic.com/business/archive/2015/06/patagonia-labor-clothing-factoryexploitation/394658/, accessed May 22016.

${ }^{85}$ Manfred Santen, Kevin Brigden, and Madeleine Cobbing, "Leaving Traces: The hidden hazardous chemicals in outdoor gear,” Greenpeace, January 2016, http://www.greenpeace.org/international/en/publications/Campaign-reports/Toxicsreports/Leaving-Traces/, accessed March 8, 2016.

86 Patagonia, "A Shell Game in the Dark," http://www.patagonia.com/ca/patagonia.go?assetid=110489, accessed May 8, 2016.

${ }^{87}$ Telephone Interview with Rick Ridgeway by Ben Gettinger, August 15, 2016.

${ }^{88}$ White, “All Your Clothes.”

${ }^{89}$ Telephone Interview with Rick Ridgeway by Ben Gettinger, April 4, 2016.

${ }^{90}$ Quoted in Bradford Wieners, “Solving Climate Change with Beer from Patagonia’s Food Startup,” Bloomberg, October 3 2016, http://www.bloomberg.com/news/features/2016-1003/solving-climate-change-with-beer-from-patagonia-s-food-startup, accessed October 22, 2016. 
91 Peter Dauvergne and Jane Lister, Eco-Business. A Big-Brand Takeover of Sustainability (Cambridge, MA: MIT Press, 2013), p. 2. 